\title{
Past and present status of the Indian Tiger in northern West Bengal, India: an overview
}

\author{
Jayanta Kumar Mallick
}

Personal Assistant to Principal Chief Conservator of Forests, Wildlife \& Chief Wildlife Warden, West Bengal;

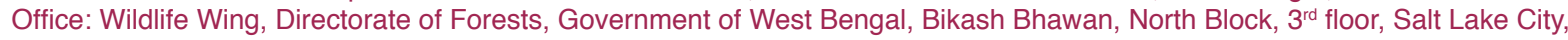
Kolkata, West Bengal 700091, India

Email: jayantamallick2007@rediffmail.com

Date of publication (online): 26 March 2010 Date of publication (print): 26 March 2010 ISSN 0974-7907 (online) | 0974-7893 (print)

Editor: L.A.K. Singh

Editor's Note: See end of this article

\section{Manuscript details:}

Ms \# o2212

Received 22 May 2009

Finally accepted 05 February 2010

Citation: Mallick, J.K. (2010). Past and present status of the Indian Tiger in northern West Bengal, India: an overview. Journal of Threatened Taxa 2(3): 739-952.

Copyright: (c) Jayanta Kumar Mallick 2010 Creative Commons Attribution 3.0 Unported License. JoTT allows unrestricted use of this article in any medium for non-profit purposes, reproduction and distribution by providing adequate credit to the authors and the source of publication.

Author Details: JAYANTA KUMAR MALLICK Postgraduated in 1974, joined the Wildlife Wing (Headquarters) in 1976 and has been working as PA to PCCF, Wildlife, West Bengal, for the last 33 years. Worked in the Project of the North-East India Task Force, IUCN/SSC/ Elephant Specialist Group and also as project consultant of the Indian Society for Wildlife Research, Kolkata. He has been involved in all departmental publications, has participated in departmental workshops, undertaken a number of studies, is looking after departmental data bank and has more than fifty published articles and study reports on wildlife conservation, particularly of mammals.

Acknowledgements: I am grateful to $\mathrm{Mr}$. Indranil Mitra for providing the G.I.S. maps and Mr. Somnath Chakraborty for retrieving relevant data. I also express my thanks to those who provided field information, to name a few - Mr. Sampat Singh Bist, I.F.S., ex-PCCF, Wildlife, West Bengal; Mr. N.C. Bahuguna, I.F.S., exDirector, Sundarban Biosphere Reserve and Mr. Subrata Pal Chowdhury, Technical Assistant (Wildlife Wing, Headquarters.
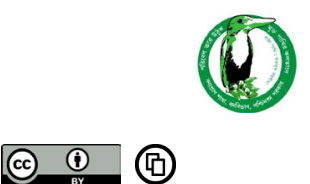

OPEN ACCESS | FREE DOWNLOAD
Abstract: Changes in the distribution range and the estimates of Tiger (Panthera tigris) populations in northern West Bengal from the late $19^{\text {th }}$ century to 2009 were examined in detail. According to a 2004 census there were 70 tigers in the region, while a 2008 estimate put the number at 8-12. The tiger survives only in protected areas of terai and duars extending over about $1000 \mathrm{~km}^{2}$ of Buxa, Jaldapara, Neora Valley and Mahananda, the Panighat and Bamanpokhri Ranges of Kurseong Division and the Chilapata and Kodalbusty Ranges under Wildlife-III Division. Tigers became extinct in Chapramari Sanctuary about a decade back; Gorumara sightings were recorded up to the 1980s. The species has already lost about $1000 \mathrm{~km}^{2}$ of its historic range in the territorial forest divisions of Darjeeling, Jalpaiguri, Cooch Behar, Dinajpur and Malda Districts. The State Forest Department has undertaken efforts involving regular monitoring, protection measures and habitat improvements and tigers are now being sighted in areas where they were absent for years. Resident tigers appear to be expanding their ranges to new areas, sometimes at higher altitudes as in Neora Valley National Park and Buxa Tiger Reserve crossing into Bhutan and Sikkim.

Keywords: corridor-development, dispersal, fragmented habitat, northern West Bengal, Panthera tigris, range collapse, new sightings, livestock-depredation, status, threats.

সাবারশ: ভারতীয় বাঘ (থ্যানথেরা টাইগ্রিস টাইগ্রিস লিলিয়াস ১৭৫৮) ঢোরাশিকার এবং মানুষের দ্বারা অন্যান্য

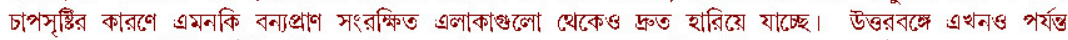

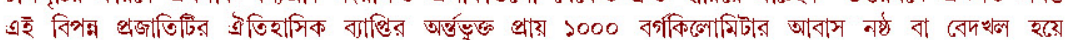

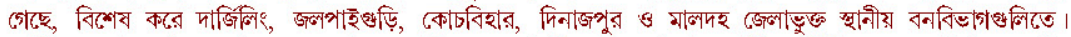

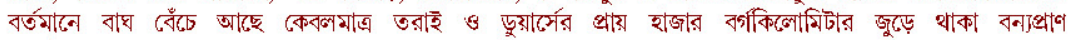
সংরক্ষিত গলাকায়। বাঘেরা কখনও এইসব জায়গা থেকেও স্থানান্তরে চটে যায়, যেমনটা ঘটেছে ২০০৯ সাটের

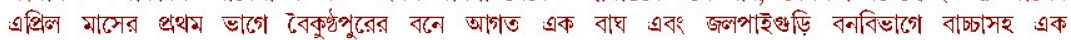
বাঘিনীর দুদশক বার্দে পুনরাবির্ভাবের ক্ষেত্রে। রোজকার পর্যবেক্ষণ, সুরক্ষ ব্যবস্থা ও আবাস উন্নয়নমূলক

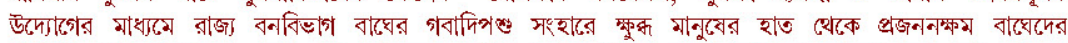

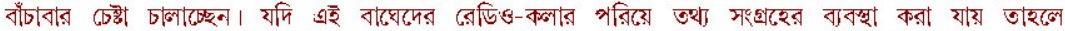
বাটেদের আধ্চলিক, আন্তঃরাজ্য ৫ আন্তঃর্জাতিক গমনাগুমনেনর ধরণধারণ এবং অন্যান্য ব্যবহারিক বিযয়ে সম্যক ধারণা নির্ভর সংরক্ষণ পরিকল্পনা প্রণায়ন ৫ তার সফল রূপায়ণ করা সম্ভবথর হবে।

\section{INTRODUCTION}

The Indian Tiger, Panthera tigris tigris Linnaeus, 1758 (Carnivora: Felidae), now occupies only $7 \%$ of its historic range. It is considered a "conservationreliant species" consequent upon its "range collapse" and threats of extinction in small fragmented habitats due to extrinsic factors such as pathogens, poaching and natural calamities, and intrinsic factors like demographic stochasticity and genetic deterioration (Maraj \& Seidensticker 2006). In northern Bengal tiger population collapse is recorded during the imperial period involving about $1000 \mathrm{~km}^{2}$ in the territorial Forest Divisions of Darjeeling district (Darjeeling, Kalimpong, Kurseong) and Jalpaiguri District (Baikunthapur and Jalpaiguri); and in Cooch Behar, Dinajpur and Malda Districts where the species was recorded during the late $19^{\text {th }}$ and early $20^{\text {th }}$ century and became extinct due to excessive anthropogenic pressures (Baker 1886; Campbell 1907; Lambourn 1918; Sengupta 1965, 1969; Burton 1989; Allen et al. 1993). In West Bengal tigers are found in a variety of habitats that range from the hill forests of Neora 
Valley and Mahananda, terai grassland of Jaldapara, the dense sal forests of Buxa and the unique Sundarbans mangrove forest (Yadav 2004b). Though the current potential tigerland in northern West Bengal is estimated to be not less than $1000 \mathrm{~km}^{2}$ (S.S. Bist, pers. comm.), Jhala et al. (2008) record tiger occupancy over only $596 \mathrm{~km}^{2}$ in the protected areas of Buxa, Jaldapara and Gorumara, without considering the habitat of the resident tiger population in Neora Valley National Park and Mahananda Wildlife Sanctuary under Wildlife Circle (north). Estimates of tiger populations in northern West Bengal on the basis of averages computed for the total landscape (including northeast) have been lower. The Wildlife Institute of India has not taken into account tigers below 1.5 years of age, which could have given rise to a lower count. However, Gorumara has been devoid of tigers for the last two decades, in spite of its potential suitability. Now that tigers have become established in two reserve forests of Baikunthapur and Jalpaiguri forest divisions, tiger land has been extended beyond the protected areas in northern West Bengal.

\section{MATERIALS AND METHODS}

Data for this study in northern West Bengal were collected from three sources: (a) survey of literature for past records of tiger; (b) information gathered through interviewing people from fringe villages, forest officials and field staff with previous or present working experience in the study area; and (c) the records on results of tiger census from 1979 to 2004, which is based on pugmark tracking. The locations of tigers in particular forest blocks or compartments during different census operations in the study area are shown in a forest map of northern West Bengal. The present forest coverage is shown in parentheses against each area within the tigerland.

The wandering and secretive nature of tigers make direct sightings and observation difficult, particularly in dense cover. Thus departmental surveys that provide data on tiger numbers and locations are mostly based on indirect evidence like pugmarks, kills, scats, scratch marks, etc., gathered at the time of regular monitoring and periodical census operations followed by computer analysis.

\section{Study Area}

Data for this study were collected from the three districts of Darjeeling, Jalpaiguri and Cooch Behar that constitute northern West Bengal, and also from the adjoining districts of Dinajpur (24 $43^{\prime} 40^{\prime \prime}-26^{\circ} 23^{\prime} \mathrm{N} \& 88^{\circ} 4^{\prime}$ $\left.89^{\circ} 21^{\prime} \mathrm{E}\right)$ and Malda $\left(24^{\circ} 41^{\prime}-25^{\circ} 32^{\prime} \mathrm{N} \& 87^{\circ} 48^{\prime}-88^{\circ} 28^{\prime} \mathrm{E}\right)$ which had tigers, historically (Image). The total recorded forest area in northern West Bengal is $3051 \mathrm{~km}^{2}: 1204 \mathrm{~km}^{2}$ in Darjeeling District, $1790 \mathrm{~km}^{2}$ in Jalpaiguri District, and $57 \mathrm{~km}^{2}$ in Cooch Behar District (Working Plans (North)
Division 2001). Out of this, the forest cover in the study area in sub-Himalayan northern West Bengal is about $2,230 \mathrm{~km}^{2}$, which is nearly $28 \%$ of the geographical area. About $1,175 \mathrm{~km}^{2}(53 \%)$ of this forest cover is designated as protected areas (Image 2). The study area belongs to the bio-geographical zones 2C (Central Himalaya) and 7B (Lower Gangetic plains) (Rodgers \& Panwar 1988).

The study area is defined on the east by the river Sankosh along the boundary of state of Assam, on the west by the river Mechi along the international border with Nepal, on the north with Bhutan and Sikkim on the south with the northern part of Cooch Behar District.

Its northern limits are hilly or slightly undulating, incorporating or adjacent to the foothills of the Himalaya (Bhabar zone). The area between the Mechi and the Teesta, comprising the forests of Kurseong Division, Mahananda Wildlife Sanctuary and western part of Baikunthapur Division is known as terai. Traditionally, the region between the Teesta and the Sankosh, including eastern part of Baikunthapur, Jalpaiguri, Kalimpong, Wildlife II and III Divisions and Buxa Tiger Reserve, is known as Bengal duars. It is the erstwhile district of Ambari Falakata within the territory of Cooch Behar Raj. In Bengal duars, the reserve forests are mostly fragmented with small isolated human populations and the corridorlinkages between these forest patches are missing in the human-dominated landscape, thereby making them vulnerable (Yadav 1998).

Numerous rivers and rivulets, flowing down from the Himalaya, cut through the study area making a web of water courses. The changes in the river courses during monsoonal floods have induced formation of extensive grassy savannas and riverine succession forest within natural tropical moist forests. The general character of the vegetation ranges from sandy riverbeds with grassy patches, Khair Acacia catechu and Sissoo Dalbergia sissoo on the recent formations, to Udal Sterculia villosa, Simul Bombax ceiba and Siris Albizzia lebbeck further inland. The grasses grown are Saccharum bengalensis, Saccharum spontaneum, Aristida cyanantha, Neyrandia arundinacea etc. This grassland habitat is preferred by the tigers as it also harbours good prey population. Some forest blocks experience frequent changes in the course of the rivers, natural and man-made fires, etc., and therefore, the characteristics of vegetation also changes. There are areas away from the river courses, above the average low land bearing dry mixed to wet mixed vegetation. Such a vegetation mosaic has also fostered a variety of wild herbivores (prey species) and carnivores (predators).

\section{Dimension and extension of 'Tigerland'}

The northern tiger habitat in West Bengal is confined mostly to Darjeeling and Jalpaiguri districts (Hooker 1854; Sunder 1889-95; O'Malley 1907; Gruning 1911; Wroughton 1916a, 1916b, 1917a, 1917b; Inglis et al. 1919; Peissel 1966; Ahmad 1981; Kurup 1989; Agrawal 
et al. 1992; Prasad 2002). Though Cooch Behar District had population of tigers in the long past (Campbell 1907; Nripendra Narayana Bhupa 1908; Narain 1927, quoted by Pocock 1941; Peissel 1966), no record of this top carnivore is available during the post-independence era.

During early $20^{\text {th }}$ century, the tiger was common in the sub-montane terai of Darjeeling District. O'Malley (1907) observes: "The tiger is met with in fairly large numbers in the plains portion of the District, as well as in the lower hills up to the height of $2,000 \mathrm{ft}(606 \mathrm{~m})$; and it is said to have been found, in a few instances, as high as 7,000ft $(2,121 \mathrm{~m})$. Man-eaters are scarce, and it is probable that in the few cases in which human beings are killed by tigers, they are not killed for the sake of food, as the place is so well stocked with game and cattle that tigers have no need to take to human flesh."

During the same period, the jungles of Cooch Behar were linked with the terai that extended up to Nepal, and there was an uninterrupted ecological link between Jaldapara and Buxa as well as Buxa and contiguous Assam on the left bank of the Sankosh River. Regarding the conditions of the Cooch Behar Raj forests, Gayatri Devi, the princess of the Cooch Behar Raj, born in 1919, records (Gayatri Devi \& Rama Rau 1982) - "This was superb terrain for wild animals, which could travel for hundreds of miles without crossing a single man-made path. All kinds of game abounded within a radius of a few miles from our palace: tiger, rhinoceros, panther, bear, wild buffalo, bison, hog deer, wild boar, and sambar... elephant."

Since the last century, the population of tiger and its habitat has got reduced significantly in the study area. Now the species is reported only from four protected areas, two in Darjeeling District and two in Jalpaiguri District, and very rarely from other territorial reserve forests (Anon. 1998; Nandy 2006). These protected areas are as below.

(i) Buxa Tiger Reserve (Alipurduar, Jalpaiguri) including national park, wildlife sanctuary (core area) and reserve forests (buffer area), lying between $26^{\circ} 30^{\prime}-26^{\circ} 55^{\prime} \mathrm{N}$ \& 89²0'-89 $55^{\prime} \mathrm{E}$;

(ii) Mahananda Wildlife Sanctuary (Darjeeling), lying within

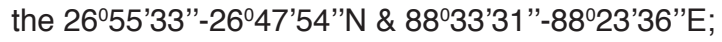

(iii) Jaldapara Wildlife Sanctuary (Jalpaiguri), situated between 25058"-27045"N \& 89008"-89055"E; and

(iv) Neora Valley National Park (Kalimpong, Darjeeling), lying within $26^{\circ} 52^{\prime} 3^{\prime \prime}-26^{\circ} 7^{\prime} 35^{\prime \prime} \mathrm{N} \& 80^{\circ} 45^{\prime}-88^{\circ} 55^{\prime} \mathrm{E}$.

Except for Neora Valley National Park, from the left bank of Tista to Khairbari forest (the island forest patch to the west of Jaldapara) in the east, there is unlikely to be any tiger at present (Bahuguna \& Mallick in press). Two erstwhile tiger-bearing protected areas - Gorumara National Park Park, situated between latitudes 26047'12.5"26043'25.6"N \& 88 ${ }^{\circ} 47^{\prime} 7.3^{\prime \prime}-88^{\circ} 52^{\prime} 4.2^{\prime \prime} E$ and Chapramari Wildlife Sanctuary, located between 26054'50.6"-
26053'02.31'N \& 88049'33.62"-88052'01.81'"E, have lost the small tiger population decades ago, as ascertained from management plans. It appears that, changes in habitat characteristics and other anthropogenic disturbances are forcing the resident tigers to leave their traditional ranges and search for new grounds in the vicinity, sometimes at higher altitudes as in Neora Valley National Park and Buxa Tiger Reserve crossing into Bhutan and Sikkim (Bahuguna \& Mallick in press).

Out of the two new sites, Nathua forest block is under Jalpaiguri Forest Division, situated on the eastern side of Gorumara National Park. It is a flat and almost level land located at an altitude of $104 \mathrm{~m}$. The river Jaldhaka flows nearby. The natural crop is composed of riverine forests, mostly Simul-Siris type. There are some patches containing chiefly 'kashia', thatch grass and 'dhadda' Saccharum longisetosum. There are also some plantation areas. The nearest tiger habitat is Neora Valley National Park on the northwest.

Another territorial forest block recently occupied by the tiger after decades is Gourikone under Baikunthapur Forest Division. A turnaround of the forest cover here has started 10 years ago with the stepping up of conservation activities. New forests came up at some places. The grass is the first seral stage of vegetation succession found in the Tista riverbed. The main grasses found here are Phragmitis karka and Saccharum munja. This grassy expanse of the Laltong Block of Mahananda Wildlife Sanctuary on the right bank of the river Tista links up Apalchand forest biotope under Baikunthapur and helps bringing back the Barking Deer Muntiacus muntjak and Spotted Deer Axis axis. It is assumed that the tiger has returned here following the deer-trail.

\section{Local extinction and present distribution pattern 1. Darjeeling District}

Tigers, known to be very fond of baby elephants, seem to follow elephant herds. Dutt-Mazumdar (1955) noticed tiger pugmarks in the Darjeeling Hills on the elephant tracks at elevations up to about $8,000 \mathrm{ft}(2,438 \mathrm{~m})$.

\subsection{Past records \\ Wildlife Division-I (277.34km²):}

Singalila National Park including Kalpokhri $\left(78.60 \mathrm{~km}^{2}\right)$ : As reported in the management plan, formerly, tigers were sometimes sighted at an altitude of $3,200 \mathrm{~m}$ in Singalila, lying between $27^{\circ} 13^{\prime} 15^{\prime \prime}-22^{\circ} 1^{\prime} 46^{\prime \prime} \mathrm{N} \& 83^{\circ} 1$ '91'"$38^{\circ} 7^{\prime} 54^{\prime \prime} \mathrm{E}$. The record of tiger at an altitude of $3186 \mathrm{~m}$ in Kalpokhri $\left(26.41 \mathrm{~km}^{2}\right)$, known as the 'valley of poison' for its medicinal resources, is also on record (Baldry 1926).

Gulma Valley (Mahananda Wildlife Sanctuary) $\left(8.88 \mathrm{~km}^{2}\right)$ : A narrow strip, covered with thatch and other grasses, is found along the Gulma khola and Choklong khola. Mr. Banerjee, Mr. Kar and Mr. Moitra went for shooting on 15 December 1929 into Gulma forest and bagged a tiger measuring 12' (Anon. 1930). 
Darjeeling Forest Division $\left(178.63 \mathrm{~km}^{2}\right)$ :

Tonglu $\left(25.08 \mathrm{~km}^{2}\right)$ : The records of occurrence of tiger in this division were available up to 1930s. The tiger was reported from the montane temperate forests of Tonglu $\left(27.03^{\circ} \mathrm{N} \& 88.09^{\circ} \mathrm{E}\right)$ in the Singalila range, $11 \mathrm{~km}$ trek from Maneybhanjan (about $27 \mathrm{~km}$ from Darjeeling) by Baldry (1926). Wood (1937) also reported presence of tiger at Tonglu forests. But, thereafter, no other record is available regarding occurrence of tiger in the westernmost forests of Darjeeling District.

Tista Valley $\left(21.40 \mathrm{~km}^{2}\right)$ : In the past, the forest tract in the Tista River valley was a favourite habitat of the tigers. They were sometimes reported from this range. They used to migrate either from the forests of Sikkim by crossing the gentler Rangit River, which meets with the turbulent Tista in this valley, dividing Sikkim and northern West Bengal, or from Kalimpong forests, after crossing the Tista River (Yadav 2004a). Since those areas were converted into agricultural fields long ago, the tigers living there did not survive in such conditions.

\section{Kurseong Forest Division (164.27 $\left.\mathrm{km}^{2}\right)$ :}

Lohargarh $\left(6.92 \mathrm{~km}^{2}\right)$ and Bamanpokhri including Balason, Lamagumba and Pankhabari $\left(20.33 \mathrm{~km}^{2}\right)$ : Hooker (1854) recorded very few tigers left in Pankhabari $\left(26^{\circ} 50^{\prime} \mathrm{N} \& 88^{\circ} 16^{\prime} \mathrm{E}\right)$ forests of upper Bamanpokhri $\left(1.60 \mathrm{~km}^{2}\right)$, causing depredation on the grazing stock of domestic cattle. The tigers were also reported from Lohargarh forests under Panighata Range (beyond the Bengdubi Military Station) next to Bamanpokhri Range and Mahananda Wildlife Sanctuary. One person was killed and another mauled by the tiger in 1987 at Marianbari Tea Estate near Balasan riverine forests $\left(3.37 \mathrm{~km}^{2}\right)$ under Bamanpokhri Range, as recorded by Mr. N.S. Rai in Bamanpokhri Rest House register (Bahuguna \& Mallick in press). In 2000 tiger census, an adult male tiger, which was known to frequent the Koklong Forest Block of Mahananda Wildlife Sanctuary and contiguous Lamagumba Forest Block $\left(2.04 \mathrm{~km}^{2}\right)$ of Kurseong Forest Division during 1999 census, was not found (Anon. 2001).

\subsection{Present records Wildlife Division-I:}

Mahananda Wildlife Sanctuary $\left(159.86 \mathrm{~km}^{2}\right)$ : Presence of the tiger in Mahananda is recorded by Guhathakurta (1966). The top carnivore is widely distributed all over the Sanctuary. The Management Plan mentions that the frequency of footprints found here reveals that the species mainly occupies the eastern and central portions of the Sanctuary. It is concentrated around Gulma Valley, where the prey species are in abundance (Yadav 2004a). One can trace tiger pugmarks along the shallow pools of Gulma Khola (a stream) and the rugged reeds of meandering Mahananda riverbed. In February and May 1995 and January 1996, tiger pugmarks were recorded at Mohargong (male), Jogijhora (male) and riverbed near hide out (male-female-cub) (WLW, WBFDCL \& NEWS 1996). Cases of Sambhar (Rusa unicolor) and Chital (Axis axis) killed by the tiger have occasionally been detected in this sanctuary.

Yadav (2001) has estimated a tiger population of more than 20. As per 2002 census, the territory occupied by the tigers $(n=15)$ covered about $97.65 \mathrm{~km}^{2}(61.08 \%$ of sanctuary area), distributed in 21 forest blocks (out of 46), namely Punding (858.74ha) and Sukna (129.16ha) [Female no.1]; Upper Champasari (316.87ha), Mahanadi (395.78ha) and Singhimari (424.59ha) [Female no.2 and Male no.1]; Jogi Jhora (470.65ha) [Female no.3]; Choklong (520.82ha) and Gulma Valley (888.69ha) [Female no.4 and Male no.2]; Upper Ghoramara (937.32ha), Silivita (171.59ha) and Ruyam (572.22ha) [Female no.5 and subadult]; Gola (605.82ha) [Male no.3], Chawa (479.55ha) [Female no.6 and her cub], Lower Ghoramara (796.02ha), north Sevoke (379.59ha) and Samardanga (267.09ha) [Female no.7 and Male no.4] and Laltong-2, 5, 10, 12 and 13 [Male no.5 and Female no.8].

In 2004, the presence of tigers $(n=16)$ was recorded from Upper Ghorama (1 sub-adult male), Kuhi (1 adult male), Ruyam ( 1 adult male and 1 adult female), Gola (1 adult female), Chawa (1 adult female), Lower Ghoramara (1 adult female), Andera (1 adult female), Lower Champasari and Mahanadi (1 adult female), Gulma (1 adult female), Bandarjhola (1 adult male), Sukna (1 adult female), Laltong (1 sub-adult female), Panchnoi and Punding ( 1 adult female and a cub), and Koklong ( 1 subadult female). Comparatively, some changes in individual occupation of territory are observed.

\section{Wildlife -II Division $\left(177.05 \mathrm{~km}^{2}\right)$ :}

Neora Valley National Park $\left(88 \mathrm{~km}^{2}\right)$ : This park was notified in December 1992. Prior to that, until 1988, only one or two tigers were found straying into the high forests of Neora Valley from the reserve forests in the foothills on the south. Shri P.K. Das (retired IFS) first records tiger pugmarks during a trekking trip in late 1980s. During late 1990s, the tigers have established a new home in the pristine forests of Neora Valley National Park (Yadav 2004b). It is anticipated that the tigers inhabiting the southern forests in the foothills preferred to move northward to the dense cover of bamboo and oak forests at Neora in search of a comparatively undisturbed and safe niche with plenty of ungulate prey species and 18 numbers of tiger were recorded from this Park during post-1998 period (Sanyal 2006).

Biswas et al. (1999) also record tigers in Thosum, East and West Nar forest blocks. During February-March, the movement of tigers along the river Neora up to an altitude of $2300 \mathrm{~m}$ in Rechila Block is reported in the $9^{\text {th }}$ Working Plan of Kalimpong Division (1997-98 to 2017-18). Yadav $(2001,2004 a)$ records at least 10 tigers in the virgin and undisturbed Hemlock and Laural forests up to $2,438 \mathrm{~m}$ 


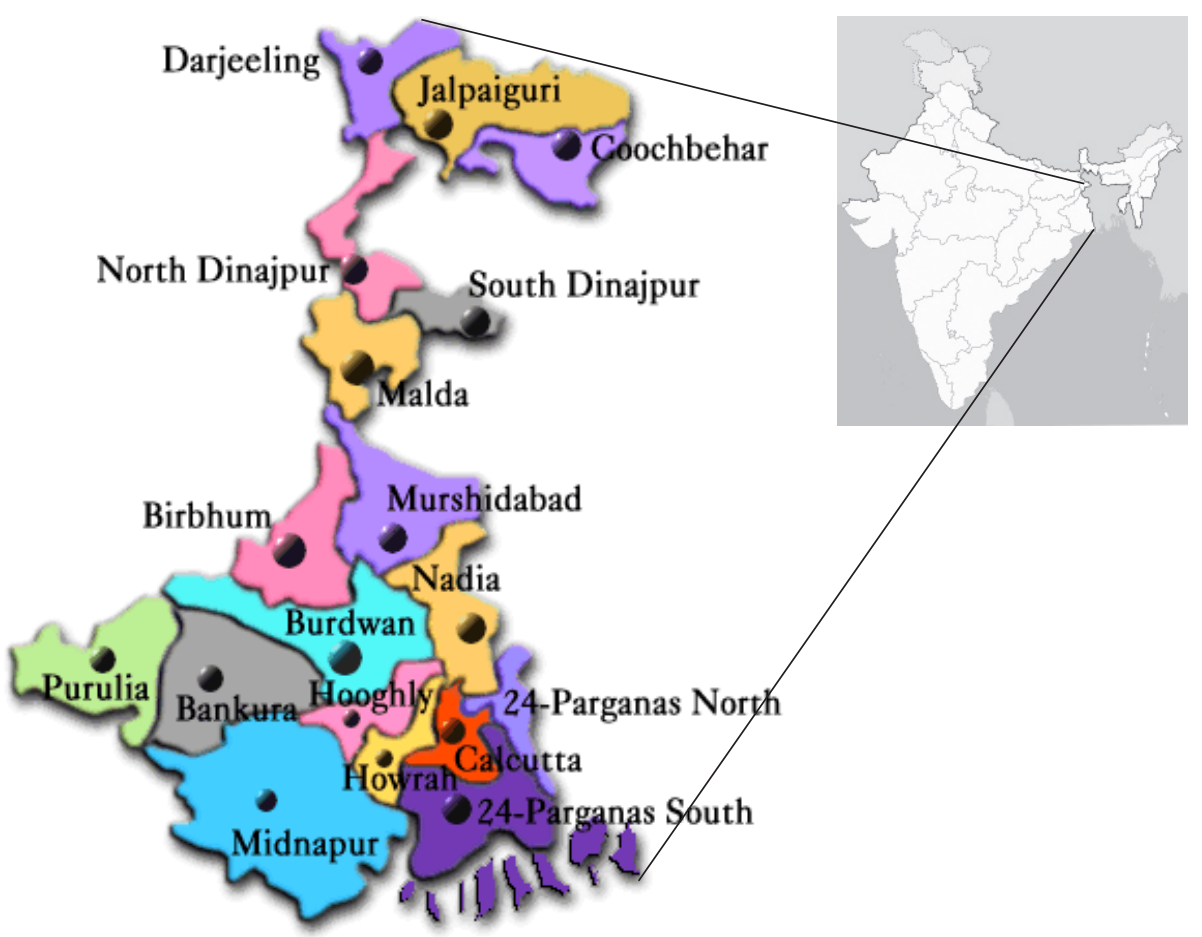

Image 1. Location map of the study area in northern West Bengal, India

and tracks to be seen at East Nar $\left(21.43 \mathrm{~km}^{2}\right)$, West Nar (20.43 $\left.\mathrm{km}^{2}\right)$ including Panchpokhri and Rechila (27.13 $\mathrm{km}^{2}$ ). A Himalayan Tahr was reportedly killed by a tiger at about $2,727 \mathrm{~m}$ altitude in 2002 , where the forest is so dense that it is impossible even for a rabbit to penetrate the bamboo patches (Bahuguna \& Mallick in press).

In 2004, the presence of tigers $(n=20)$ was recorded from East Nar (5: 3 adult males, 1 adult female and 1 cub), Rachila (11: 3 adult males and 8 adult females), Rhenok (1 adult female) and Thosum (4: 1 adult male, 2 adult females and $1 \mathrm{cub}$ ) forest blocks.

During the tiger census 2008, evidences of tigers were found at Reshit and Rachila in Upper Neora as well as Thosum and East Nar of Lower Neora. The exact number of tigers is not determined at the time of preparation of the manuscript.

Kalimpong Forest Division $\left(429 \mathrm{~km}^{2}\right)$ :

There has been an increase in the number of tigers in the blocks under Chel Range (Anon. 1971). One forest villager was alleged to have been killed by a tiger at East Nar under Jaldhaka Range. At present, one or two tigers are recorded from the forests of this division.

\section{Jalpaiguri District}

Tigers were common in Jalpaiguri District during the early $20^{\text {th }}$ century (Inglis et al. 1919). A population is now present only in Buxa Tiger Reserve and Jaldapara Wildlife Sanctuary (Wildlife Division-III), not in Gorumara National Park and contiguous Chapamari Wildlife Sanctuary under Wildlife Division-II. Except for Neora Valley National Park under Wildlife Division-II, from the left bank of Tista to Khairbari forest (under Baikunthapur, Jalpaiguri and Wildlife III Divisions) in the east, there is unlikely to be any tiger (Bahuguna \& Mallick in press). Mr. Subimal Roy, retired Chief Wildlife Warden, West Bengal, thinks that this is due to poaching (pers. comm.). Recently, two new habitats have been added in Jalpaiguri District.

\subsection{Past Records}

Cooch Behar Forest Division (now Wildlife DivisionIII): Narain (1927) describes an encounter between a wild buffalo and a pair of tigers in duars along a riverbed on the borders of Bhutan: "...a magnificent bull buffalo moving along leisurely with on each side a tiger (probably tiger and tigress). Every now and then one tiger would dash in to try and get a hold, and the buffalo would merely sweep his horns. The tigers were evidently sparring for an opening... This went on for about half a mile when suddenly one of the tigers got too close, and the buffalo immediately ripped it right up with his horns and the beast died at once. The other tiger bolted and the buffalo carried on unconcernedly". In 1922, as reported by Victor N. Narayan, two pure white tigers, a male and a female, about three-quarters grown, with pink eyes were shot in the former State of Cooch Behar (quoted by Daniel 2001).

Jaldapara: Ahmad (1981) describes a tiger shooting in Chilapata forests during 1940s.

\section{Jalpaiguri Forest Division $\left(429 \mathrm{~km}^{2}\right)$ :}

Ramshai $\left(14.89 \mathrm{~km}^{2}\right)$ : Rowland Ward's record of the largest tiger, shot at Ramsai, duars in Bengal, by Colonel 
Evans Gordon, was 10'7" (317cm) before skinning (Ward 1903). Presence of tiger here is recorded up to 1960s. One man was killed and another one moulded at Ramshai during 1968-69 (Anon. 1971).

Panjhora $\left(22.54 \mathrm{~km}^{2}\right)$ : A forest villager was killed by a tiger in this forest block (Anon. 1971).

Moraghat $\left(47.43 \mathrm{~km}^{2}\right)$ : In 1999, a tiger was reported in this forest area. Though Moraghat is not the usual habitat of tiger, it is sometimes used as an old-age home of the tiger. The old tigers, driven out by young tigers from the neighbouring forests, take shelter there (Bahuguna \& Mallick in press).

\section{Wildlife Division-II Division:}

Gorumara National Park $\left(79.45 \mathrm{~km}^{2}\right)$ : No tiger is recorded at present from this national park. Besides the Great Indian One-horned Rhinoceros, Gorumara National Park serves as an important biological corridor for sustaining the population of wild elephants in northern West Bengal between Tista and Torsa rivers. A large number of Gaur also utilize this park along with other herbivorous species. In the past, the tigers used to roam in Gorumara forests and around (Sanyal 2006). Gupta (1958) gave a dreadful account of tiger predation on rhino calf in Gorumara: "About November, 1951, a cow-rhino with a very small calf was frequently seen. A tiger was after this calf, and one afternoon in early December... the tiger went for the calf. The cow at once charged the tiger, and a fearful battle ensued about 300 yards from the platform... the battle was inconclusive. About three weeks later I saw the cow-rhino and her small calf again. The calf looked normal, but the cow was emaciated, bore deep claw marks, on both flanks, and seemed to walk slowly with some difficulty. In the third week of January 1952, the second and the concluding round of battle was fought during the night, and the poor, much weakened rhinoceros was killed together with her calf... I found the remains of the two animals on the right bank of the Indong, a little upstream of Gorumara. This time there were two tigers, and the calf had been completely eaten together with about a third of the cow."

Anonymous (1976) records that only one big female tiger is seen in Gorumara. A pair of young tiger and tigress frequently used to visit this protected area.

Predation by tigers on rhino cows and calves as a factor in keeping down the population of rhino is in records, and the incidents were in Gorumara during 1952 when two (mother and calf) rhinos got killed; outside the sanctuary one calf got killed in 1968-69; and in Jaldapara during 1981 one calf got killed (Bist 1994).

Gorumara had its own core population of tiger up to 1980 s, which got decimated subsequently. A couple of tiger was reported in Gorumara in the past but later there were no direct sightings or indirect evidences like pugmarks (Pratihar \& Chakraborty 1996). The management plan of Gorumara National Park (2007-08 to
2017-18) also records absence of the tiger since 1980s. During census operations in 1992, 1993, 1997 and 1999, no tiger was found in Gorumara (Anon. 2000). Again, during tiger census in 2002 and 2004, no trace of tiger was available in this park. Hence it was assumed that the tiger is extinct in Gorumara and its surrounding areas. However, Martin (1996) states that in 1994-95, a female rhino calf was reportedly killed by the tiger in Gorumara.

\section{Chapramari Wildlife Sanctuary $\left(9.6031 \mathrm{~km}^{2}\right)$}

In spite of existence of a good habitat for large carnivores, this sanctuary does not have any tiger, which it once had. Tiger is, however, present in Neora Valley and Mal Forest Block, to the north and northwest of this sanctuary. However, there is possibility of the tiger descending down from Neora Valley National Park, exploring its new territories amidst the rich potential preybase of Chapramari.

\section{Buxa Forest Division}

Known for the organized tiger hunts for the sahibs during the pre- and post-independence era, tiger population in Buxa is critically low (Ghosh 1998). Hunting statistics of erstwhile Buxa Forest Division, the biggest in north Bengal, show that within a period of 20 years (1930-1950) 150 tigers were killed, whereas 36 tigers were hunted between 1955-56 and 1967-68 due to the restrictions imposed on hunting (Management Plan). Tigers of northern West Bengal nullify the concept of territorialism and owing to heavy concentration per unit area several tigers were shot over one kill in course of few hours (Chaudhuri \& Chakrabarti 1979). The visitor's books of Rydak and Bholka Forest Rest House of Buxa Forest Division testify to scores of tiger having been shot by the Governor's shooting party in a span of 3-4 days in early and mid-thirties (Chaudhuri \& Chakrabarti 1979). In early 1933, the then governor of Bengal, John Anderson, along with the Conservator of Forests, Edward Oswald Shebbeare and a number of other high-ranking officials, stopped for four days at the Rydak inspection bungalow, which was built by the British in 1908 to serve as a hunting and shooting camp. Between February 10 and 13, these hunters shot down two tigers in the nearby Tiamari forest. On the afternoon of the $12^{\text {th }}$, a tiger killed one Sergeant Adams in the same forest. While Anderson left on the $13^{\text {th }}$, three police officers - Deputy Inspector General P. Walker, Superintendent of Police E. Holdon and Commissioner Drummond - stayed back for another five days, killing two more tigers just behind the bungalow on the bank of the Dhaowlajhora.

Ahmad (1981), who was the Divisional Forest Officer of Buxa Division during 1939-42, writes: "The two eastern ranges, Rydak and Sankos, were particularly suitable for shooting tigers... The tigers frequently moved from one area to another and could always be put up for the shoot. Rydak was largely a tree forest but along the bank of the 


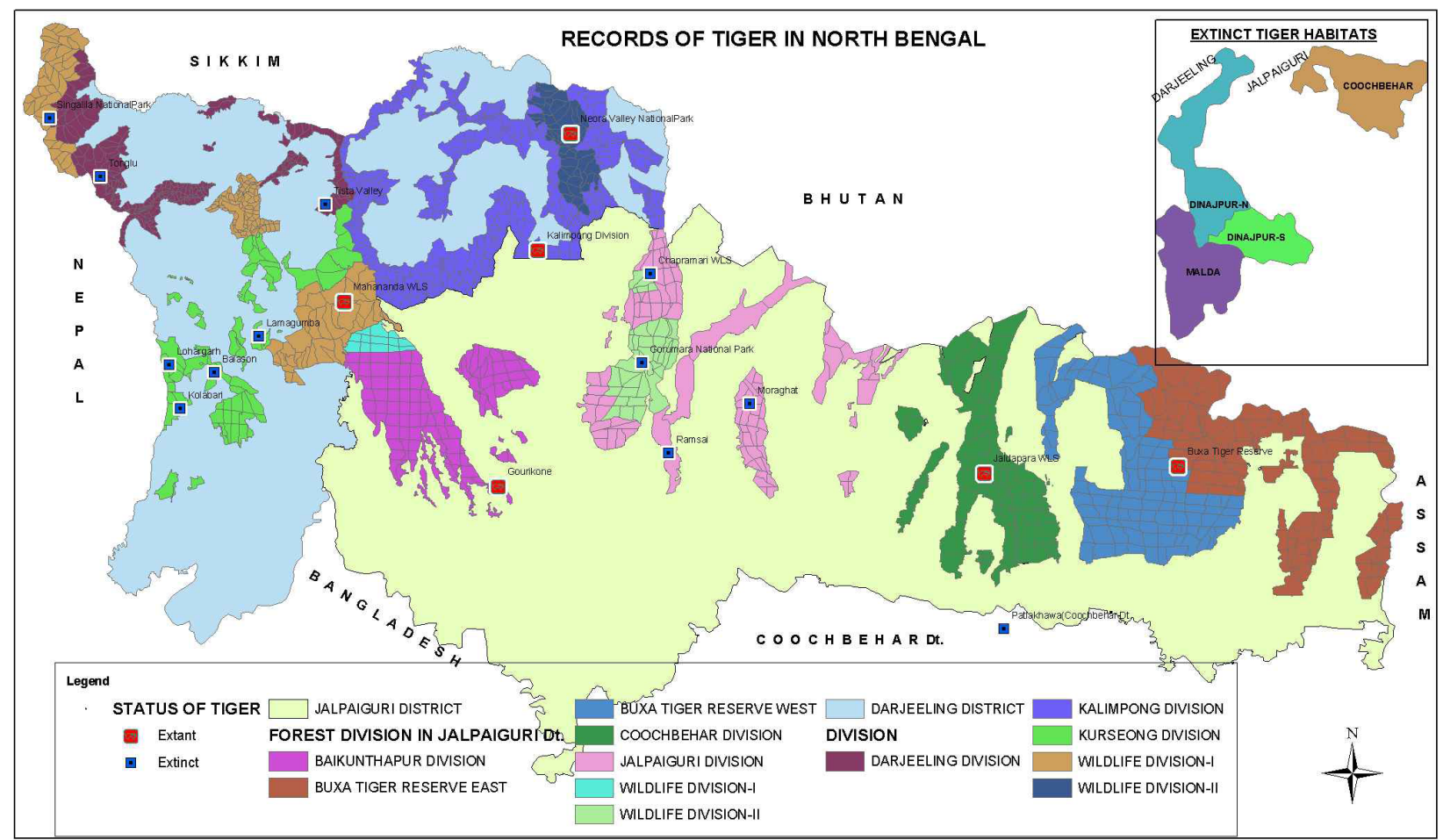

Image 2. Past and present tiger habitats in northern districts of West Bengal

river Rydak on the east there were patches of grassland, which could be beaten for the tiger. There were cane breaks on the south interspersed by smaller rivers, which were also good habitats for the tiger. V.I.P. shoots were mostly organized in Buxa Division." A 9'6" $(285 \mathrm{~cm})$ tiger was shot in this forest (Ahmad 1981).

\subsection{Present Records}

Gourikone $\left(9.68 \mathrm{~km}^{2}\right)$ under Baikunthapur Forest Division $\left(226.29 \mathrm{~km}^{2}\right)$ : It is reported that two Royal Bengal Tigers have been sighted in the duars forests of northern West Bengal. The tigers have been sighted by the forest personnel in the Baikunthapur forests after a gap of 20 years. Carcass of a cow was detected in the Gourikone forest block under Belacoba Range and the tiger's presence in the secluded forest was subsequently confirmed. Here, the forest areas are dotted with tall grass and inhabited by deer and other herbivores, providing an ideal habitat for this top predator.

The Conservator of Forests, Northern Circle, observes: "I spotted the young tiger in January (2009) when I was inspecting the forest along with the local beat and range officers. The tiger stood on our path, gave us a close look and then moved away. Initially we thought it was a big leopard but the black stripes on its body and walking style confirmed it was a Bengal tiger. The tiger was about 8'6" $(2.6 \mathrm{~m})$ long and we have collected its pugmarks. It seems the return of prey animals like the Barking Deer and the Spotted Deer has lured the tiger back."

\section{Jalpaiguri Forest Division, Jalpaiguri (429. $\left.\mathrm{km}^{2}\right)$}

Nathua $\left(21.38 \mathrm{~km}^{2}\right)$ : Recently, another tiger sighting is recorded in the Nathua Beat under Nathua Range. The locals have spotted the tiger and the forest workers have collected its pugmarks. A forest guard saw the tiger in this forest near the Jaldhaka River on 02 November 2008 from a $50 \mathrm{~m}$ distance and the locals spotted the predator near the same spot the next day. On 06 November, the Divisional Forest Officer, Jalpaiguri Division, visited the spot and collected the pugmarks, which were $15.40 \mathrm{~cm}$ in length, and $14.30 \mathrm{~cm}$ in breadth, suggesting that it is an adult male, about 5' $(152 \mathrm{~cm})$ long. The tiger is roaming in the forest between the Jaldhaka and Diana rivers. On 16 March 2009, the Divisional Forest Officer submitted a report to the Conservator of Forests, Wildlife (North) Circle. Subsequently, a team of forest officials including the Chief Conservator of Forests, wildlife (North) and the Divisional Forest Officer, Jalpaiguri Forest Division, visited the Nathua forest to survey the situation. The area between the rivers Diana and Jaldhaka is now covered with natural grassland, which could further be extended and developed into an ideal habitat for the tigers. Hence, the forest officials have decided to develop this riverine grassland. They are also deploying special vigilance for the security of the endangered predator.

\section{Wildlife-III Division, Cooch Behar $\left(315 \mathrm{~km}^{2}\right)$}

Jaldapara Wildlife Sanctuary $\left(216.51 \mathrm{~km}^{2}\right)$ : Though Jaldapara is famous for the rhinoceros, it also provides excellent habitat for the tiger. Both food and cover are 
adequately available for the large carnivores. Here, the tigers prefer open grassland with good water sources, avoiding the dense savannah. They are concentrated in parts of Malangi, Jaldapara, Torsa and Chilapata blocks (Management Plan 1997-98 to 2006-07). These blocks have good natural water sources like Chirakhawa, Sissamara, Buritorsa, Sukta, Sukti, Malangi, Kalijhora etc.

During the first enumeration conducted on 21 May 1964 in Jaldapara, more than two tigers were reported (Das 1966), whereas the number of tiger is reported to be 12 during the census conducted in the first week of September 1968 (Anonymous 1971). But only one tiger was recorded during the census on 19 and 20 February 1974 (Anonymous 1976). During 1975 and 1978 the number of tiger in this Sanctuary was shown as four (Management Plan 1997-98 to 2006-07). However, 12 numbers of tigers were reported in 1980. In 1985, only three could be tracked from the pugmarks. The figures recorded in subsequent census are seven in 1988, five in 1992, and in 2004 it was three (two adult males and one adult female) from Jaldapara forest block $\left(34.51 \mathrm{~km}^{2}\right)$, two adult males in Hasimara forest block $\left(16.42 \mathrm{~km}^{2}\right)$ and one adult female in Barodabri forest block $\left(6.09 \mathrm{~km}^{2}\right)$.

A tiger was reportedly poached in Torsa-1 compartment of T.E.C. Beat in February 1990. The tiger seems to avoid the adult rhinoceros. However, there are periodic instances of rhino calf being killed by tiger in 1974, 1991 and 1995 in Jaldapara (pers. comm. S. Roy). One elephant calf also died due to attack by a tiger in February 1992. Killing of two out of 6 numbers of 'Gayals', released among the wild gaur herd in 1963-64, by tiger is also reported (Anonymous 1969).

\section{Buxa Tiger Reserve}

Buxa Tiger Reserve is the largest chunk of forest in north Bengal and has the second highest tiger population in West Bengal after Sunderbans. Before creation of Buxa Tiger Reserve in 1983, the tiger population in erstwhile Buxa Forest Division was 17 in 1972 and 27 in 1979 (Mallick \& Mitra 2002). The entire forest area of Buxa Tiger Reserve, except for a small patch of upper ridges between $1700 \mathrm{~m}$ to $1800 \mathrm{~m}$ latitude, is suitable habitat for the tigers. The tiger is distributed over Kumargram, Newlands, Bhutanghat, Phaskhawa, Jainty, Tashigaon, Raimatang, Santrabari, south Rajabhatkhawa, north Rajabhatkhawa, Dima and Nimati blocks as per 1997 tiger census. Chaudhuri \& Sarkar (2004) record distribution of the tigers in bhabar area around Jainti and Raimatang. Yadav (2004b) estimated a population of 2530 individuals in the Sal (Shorea robusta) and riverine forests and even in the hilly terrain. During 2005 sudden decline of the tiger population in Buxa Tiger Reserve to only 4 is anticipated by Sanyal (2006). During 2007 tiger census in Buxa Tiger Reserve evidences of tiger's existence were found in between Raimatang jhora, Dima,
Buxa jhora, Bala, Jayanti, Baje khola and Khururi jhora. Presence of a minimum of 12 tigers (four adult males, six adult females and two cubs) is recorded during this census (Anon. 2008b).

Buxa serves as the critical corridor between the forests of the adjoining Assam and Bhutan. This connection should not be prima facie ruled out (Sanyal 2006). It is apprehended that some of the tigers might have migrated from Buxa to the adjacent higher hills of Bhutan.

\section{Cooch Behar District: Past records}

Patlakhawa Reserve Forest $\left(16.48 \mathrm{~km}^{2}\right)$ : A few tigers were found in the Patlakhawa Game Reserve (erstwhile hunting ground of the Maharaja of Coochbehar), located just on the northern border with Jalpaiguri, having ecological boundary with Jaldapara Wildlife Sanctuary (Chaudhuri 1903; Nripendra Narayana Bhupa 1908; Bhaduri 1966). There were shooting-camps two or three times a year at one of the two reserves either at Patlakhawa or at Takuamari (Gayatri Devi \& Rama Rau 1982). The Maharajahs only hunted primarily in February-March. On 18 February 1907, the Maharajah and party killed seven tigers at Saralbhanga river in Kachugoan Division of Assam, bordering Bhutan. On 16 March 1903 he and his party hunted five tigers on the Jorai nullah at Barobisha under present Buxa Tiger Reserve, in 12 minutes. In 1902, on two separate occasions, the day's bag included four tigers. Between 1871 and 1907, 365 tigers were killed on the domains of the Maharajah (Barclay 1931). The Maharajah of Cooch Behar showed Robert A. Sterndale one of the skulls being 15" of a young tiger (Sterndale 1982). In 1890, he shot a 10'21/2" $(306.25 \mathrm{~cm})$ tiger and a 9'3" $(277.5 \mathrm{~cm})$ tigress. Long ago, white tigers were reportedly killed in Cooch Behar (Chaturvedi 1970).

\section{Dinajpur District $\left(18 \mathrm{~km}^{2}\right)$ : Past records}

Dinajpur has freshwater swamps. Burton (1989) mentions one albino tiger shot at Dinajpur in early $20^{\text {th }}$ century.

\section{Malda District $\left(20 \mathrm{~km}^{2}\right)$ : Past records}

Malda along with contiguous Purnea on the west (Santal Parganas, now in Bihar) was considered to be one of the best localities for tiger shooting in Bengal (Russell 1900). Hinjal (Barringtonia acutangula) is the characteristic species that occurs in the freshwater swampy land (beel), low-lying trough-shaped basins connected with various rivers and tributaries. The undergrowth consists of various grasses like Saccharum arundinaceum and Desmostachya bipinnata, Phragmites karka, etc. However, no record of the tiger in this district is available since the beginning of $20^{\text {th }}$ century.

\section{Tiger Census}

Tiger census operations are periodically conducted in northern West Bengal by the forest department. The 
Table 1. Population of tiger in northern West Bengal during 1979-2004

\begin{tabular}{|c|c|c|c|c|c|c|c|c|c|c|c|}
\hline ¿ & 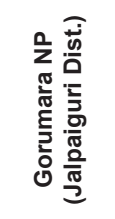 & 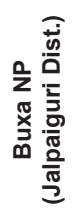 & 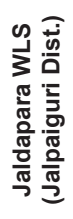 & 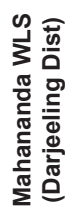 & 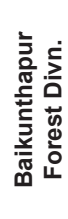 & 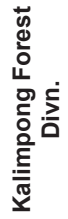 & 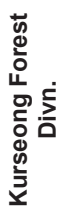 & 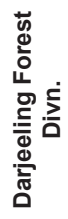 & 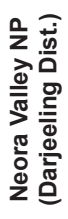 & $\begin{array}{l}\bar{\pi} \\
\text { 음 }\end{array}$ & 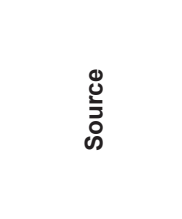 \\
\hline 1979 & 07 & 27 & 12 & 10 & 07 & & & & & 63 & Raha 1996 \\
\hline 1984 & 16 & $15^{1}$ & 09 & 10 & 08 & & & & & 58 & $\begin{array}{c}\text { Raha } 1996 \\
\text { 'incomplete } \\
\text { census }\end{array}$ \\
\hline 1985 & & & $3^{2}$ & & & & & & & & $\begin{array}{c}{ }^{2} \text { Management } \\
\text { Plan 1997-98 to } \\
2006-07\end{array}$ \\
\hline 1989 & 08 & 33 & 07 & 08 & NA & & & & & $56+$ & Raha 1996 \\
\hline 1992 & - & 29 & 05 & 13 & NA & & & & & $47+$ & Raha 1996 \\
\hline 1993 & - & 29 & 09 & 12 & 09 & & & & & 59 & Raha 1996 \\
\hline 1995 & $\begin{array}{l}{ }^{3} \mathrm{r} \mathrm{h} \mathrm{i} \mathrm{n} \mathrm{o} \\
\text { calf killed } \\
\text { by tiger }\end{array}$ & $31^{4}$ & & & & & & & & & $\begin{array}{l}{ }^{3} \text { Martin, } 1996 \\
{ }^{4} \text { Management } \\
\text { Plan }\end{array}$ \\
\hline 1997 & - & 32 & 13 & 12 & 02 & 01 & 02 & 01 & - & 63 & Ghosh 1998 \\
\hline 1999 & & 33 & 12 & 13 & \multicolumn{4}{|c|}{ "Others" = 5} & 18 & 81 & Thapliyal 2001 \\
\hline 2002 & & 31 & 09 & 15 & 02 & 02 & & & 19 & 78 & Anon. 2004 \\
\hline 2004 & & 27 & 06 & 16 & - & 01 & & & 20 & 70 & Anon. 2008a \\
\hline
\end{tabular}

Table 2. Population composition of tiger in northern West Bengal during 1997 (Ghosh 1998)

\begin{tabular}{|l|c|c|c|c|c|c|}
\hline Division & $\begin{array}{c}\text { Sub-adult } \\
\text { male }\end{array}$ & $\begin{array}{c}\text { Adult } \\
\text { male }\end{array}$ & $\begin{array}{c}\text { Sub-adult } \\
\text { female }\end{array}$ & $\begin{array}{c}\text { Adult } \\
\text { female }\end{array}$ & Cub & Total \\
\hline Buxa & 11 & 02 & 12 & 06 & 01 & 32 \\
\hline Jaldapara & 02 & 03 & - & 06 & 02 & 13 \\
\hline Mahananda & 02 & 04 & 02 & 03 & 01 & 12 \\
\hline Kalimpong & - & 01 & - & - & - & 01 \\
\hline Baikunthapur & - & 02 & - & - & - & 02 \\
\hline Kurseong & - & 01 & - & 01 & - & 02 \\
\hline Darjeeling & - & 01 & - & - & - & 01 \\
\hline Grand total & 15 & 14 & 14 & 16 & 04 & 63 \\
\hline
\end{tabular}

*Neora Valley population was not discovered during 1997.

results are shown in Tables 1 to 5 . As per 1999 tiger census, the total tiger territory in Buxa comes to $343 \mathrm{~km}^{2}$ or $45.20 \%$ of the total tiger reserve area and this time tigers are found in six new forest blocks reportedly not occupied during earlier censuses, whereas presence of tigers in six blocks recorded earlier was not traced (Mallick \& Mitra 2002). Tigers were not found in the forests along the fringe and dispersal of sub-adult tigers from their natal areas towards unoccupied habitat was also observed (Mallick \& Mitra 2002).

During tiger census in 2007, Buxa Tiger Reserve had a population range $12-20$ occupying about $600 \mathrm{~km}^{2}$ forests and other areas of North Bengal 8-12 (Anon. 2008a). In Wildlife Division-III alone, there were 10 reports of sighting of tigers, five cases of killing of wild herbivores by tigers and 20 cases of lifting of cattle by tigers during 2007. However, Jhala et al. (2008) show only 8-12 (average 10) tigers for the whole region, though this report has excluded four known tiger habitats, viz. Neora Valley National Park, Mahananda Wildlife Sanctuary, Kurseong Division (Panighata and Bamanpokhri ranges) and Chilapata and Kodalbusty ranges under Wildlife-III Division of the tiger in the region. A person was reportedly killed on 05 February 2006 by a tiger in Kalabari forest village under Kurseong Division. In November-December 2007, tiger scats and pugmarks were collected in Buxa Tiger Reserve mainly from Bhutri, Pana, Adma, Chunabhati, Raimatong, Santrabari, Tashigaon, Tobgaon, Phaskhawa, Jainti, 
Table 3. Population composition of tiger in northern West Bengal during - 1999 (Thapliyal 2001)

\begin{tabular}{|l|c|c|c|c|}
\hline Protected Areas & Male & Female & Cub & Total \\
\hline Buxa & 15 & 16 & 02 & 33 \\
\hline Jaldapara & 05 & 07 & - & 12 \\
\hline Mahananda & 06 & 06 & 01 & 13 \\
\hline Neora Valley & 06 & 09 & 03 & 18 \\
\hline Others & 04 & 01 & - & 05 \\
\hline Grand total & 36 & 39 & 06 & 81 \\
\hline
\end{tabular}

Table 4. Population composition of tiger in northern West Bengal during 2002 (Anon. 2004)

\begin{tabular}{|l|c|c|c|c|c|c|c|}
\hline \multirow{2}{*}{$\begin{array}{l}\text { Protected } \\
\text { Areas }\end{array}$} & \multicolumn{2}{|c|}{ Adult } & \multicolumn{3}{c|}{ Sub-adult } & \multirow{2}{*}{ Cub } & \multirow{2}{*}{ Total } \\
\cline { 2 - 7 } & M & F & M & F & U & & \\
\hline Buxa & 04 & 07 & 09 & 07 & - & 04 & 31 \\
\hline Mahananda & 05 & 08 & - & - & 01 & 01 & 15 \\
\hline Neora & 07 & 10 & - & - & 02 & - & 19 \\
\hline Jaldapara & 03 & 05 & - & - & - & 01 & 09 \\
\hline Baikunthapur & 01 & 01 & - & - & - & - & 02 \\
\hline Kalimpong & - & 01 & - & - & 01 & - & 02 \\
\hline Grand total & 20 & 32 & 09 & 07 & 04 & 06 & 78 \\
\hline
\end{tabular}

M - Male; F - Female; U - Unsexed

Table 5. Population composition of tiger in northern West Bengal during 2004 (Bhutia 2005; Anon. 2008a)

\begin{tabular}{|l|c|c|c|c|}
\hline Areas & Male & Female & Cub & Total \\
\hline Buxa* & 09 & 15 & 03 & 27 \\
\hline Mahananda & 05 & 10 & 01 & 16 \\
\hline Neora Valley & 07 & 11 & 02 & 20 \\
\hline Jaldapara & 04 & 02 & - & 06 \\
\hline Baikunthapur & - & - & - & - \\
\hline Kalimpong & 01 & - & - & 01 \\
\hline Grand total & 26 & 38 & 06 & 70 \\
\hline
\end{tabular}

*The hilly forest tract bordering Bhutan could not be fully covered during the census, because of operation "ALL CLEAR" in Bhutan.

Panbari, South Rajabhatkhawa, Damanpur, Nimati, Newlands, Kumargram and Sankos forest blocks, mostly located in the northern part of the reserve (Bhutia 2005; Anon. 2008b).

\section{Dispersal/Migration Records}

Wherever wild tigers still exist, their habitat often encompasses national borders, such as the Sundarbans between India and Bangladesh, and the border between Buxa and Manas Tiger Reserves in the east and Bhutan in the north. However, tiger migration, which is often reported every year within the state and across the border, has not so far been monitored or studied. Habitat destruction is forcing the endangered tigers to seek for new grounds, including high mountains which have a good prey-base but are not known to be the natural home of the big cats.

A number of cases of movement of tigers to nontraditional areas have been reported in the country in recent years. (a) The researchers of the Wildlife Institute of India, while combing the Trishna Reserve Forest in Tripura for census of Gaur, had seen one tigress and two cubs on several occasions in May 2005. Tigers have not been seen in this forest earlier since 1976; (b) In September 2007, experts sighted up to 20 tigers in a hilly tropical rainforest in Maharashtra, almost three decades after it was thought that poaching had wiped them out there; (c) Increase in the density of tiger (3-5 tigers per $100 \mathrm{~km}^{2}$ ) in Rajaji National Park is recorded by Harihat et al. (2009), probably due to immigrating tigers from the nearby Corbett Tiger Reserve; (d) In November 2008, pugmarks of an adult tigress and cubs have been found in Nagra Village in Shahjahanpur, some $250 \mathrm{~km}$ from Lucknow, Uttar Pradesh, which has no forest around. The tigers have strayed from the Dudhwa Tiger Reserve, located in the neighbouring Lakhimpur Kheri District; (e) Pugmarks of an adult female tiger were reportedly found in April 2009 in the high altitude Pangolakha, Sikkim, along the Bhutan border.

Similarly, tigers are reported to migrate in between northern West Bengal, Bhutan and Sikkim. Normally they enter the state from Lava $(2,126 \mathrm{~m})$, which is $33 \mathrm{~km}$ from Kalimpong towards northeastern Sikkim. As reported, tigers have been located in Baikunthapur Division east of Mahananda Wildlife Sanctuary and Nathua forests under Nathua Range of Jalpaiguri Division south of Neora Valley National Park. It is presumed that the tigers tend to migrate through the corridor along the riverine tract (westeast or north-south) in the study area.

A biological corridor to maintain the movement of tiger is reported to exist between Arunachal sub-Himalayan forests, Assam and Bhutan to Buxa Tiger Reserve in West Bengal (MOEF 2000). Phipsu Wildlife Sanctuary of Bhutan is situated in the northern boundary of Buxa Tiger Reserve (Management Plan). Considering the continuous distribution and ranging of wild animals in the Tiger Reserve and in its vicinity, it is seen that the ecological boundary on the north extends upto approximately $2.0 \mathrm{~km}$ within Bhutan across the Indo-Bhutan border along the contiguous forest. The natural saltlick at Khurul/Kalikhola is also situated beyond this international border. Like the elephants and gaurs, tigers in Bhutan move from Phibsoo Wildlife Sanctuary to the Manas Tiger Reserve and three reserved forests of Assam and to Buxa Tiger Reserve and Chilapata Range of Jaldapara Wildlife Sanctuary of West Bengal (Anon. undated). They might be pioneer explorers and may have returned to the previous locations.

\section{Threats}

The tiger crisis is now reasoned to be solely anthropogenic (Sanyal 2006; Dinerstein et al. 2007; 
Reddy 2008). Over the last century, major and rapid changes took place in the topography of the study area due to expansion of human habitation, increased agriculture, establishment of tea gardens, urbanization, fragmented wildlife habitat, added to which were large scale hunting by the British administrators and Indian royal family members, and depletion of major prey species and poaching (Ahmad 1981; Nandy 2006).

In northern Bengal, the shooting of tigers was controlled by three game associations from 1926 to 1958 and the practice was banned from December 1962 . These associations were Darjeeling Shooting and Fishing Club, Teesta-Torsa Game Association, and Torsa-Sankosh Fishing and Shooting Association. No rewards, however, were paid and two tigers were allowed per permit per annum (Bist 1997; Management Plan 2000; Daniel 2001). In 1991-92, one tiger was poached in Panighata block of Kurseong Forest Division and another tiger at Laltong-14 in Mahananda Wildlife Sanctuary in 1993-94.

Many of the savannahs and grasslands, particularly those outside the protected areas, have been converted to valuable timber species during the colonial period. For example, most of the grasslands by the side of the Rydak and other rivers in Buxa had been planted with valuable teak trees before this area was declared as tiger reserve (Sanyal 1992).

Strict fire control measures have also resulted in invasion of woodland over grasslands. These have caused reduction of the preferred habitat of both the prey and predator species. In northern West Bengal, the affected areas are Sankosh, Bholka, Bhutri and Godamdabri in Buxa Tiger Reserve, Titi and Khairbari in Jaldapara Wildlife Sanctuary, Gorumara National Park, parts of Baikunthapur and Jalpaiguri Divisions in Jalpaiguri District, Patlakhawa and Garodhat reserves in Cooch Behar District.

During the $20^{\text {th }}$ century, estimated loss of the pure and mixed grassland areas was $150-190 \mathrm{~km}^{2}$ in the protected areas of duars in northern West Bengal $\left(30-40 \mathrm{~km}^{2}\right.$ in Sankosh-Rydak in Buxa, $70-90 \mathrm{~km}^{2}$ in Torsa in Jaldapara and Cooch Behar and $50-60 \mathrm{~km}^{2}$ in Jaldhaka-Diana in Gorumara) (Bist 1994). Mineral (dolomite) extraction industries have also threatened the tigers in Buxa Tiger Reserve (Mishra 1998; Rajvanshi 2001).

The first case of tiger-train collision was reported "recently". One adult male tiger, nearly 13 years old, 8'5" $(2.6 \mathrm{~m})$ in length from nose-tip to tail-tip, was found dead at Barasoulmari Village near the Dolong Tea Estate in Falakata on railway track between $94 / 3$ and $94 / 4$ km, P.S. Ghoksadanga, Coochbehar District. The post mortem report revealed that the facial bones of the tiger had been smashed due to the impact of this collision. Moreover, four ribs were discovered to be broken and the lungs were damaged. The carcass was burnt later near Shiltorsha in Jaldapara forests. It is anticipated that this victim could have strayed from the Jaldapara Wildlife Sanctuary into the area about $6 \mathrm{~km}$ away.

However, unlike the Sundarbans, man-tiger conflict is not so acute in northern West Bengal. Sometimes the livestock of the villagers are left to graze freely in the forests and they are prone to tiger depredation, especially in areas where the prey is scarce and such conflict has led to retaliatory activities like poisoning of carcasses for eliminating the predator without realising the importance of prey-predator relationship and the impact of retaliation in the wild, leading to increasing population of the ungulates and intensity of crop-raiding by these herbivores.

\section{DISCUSSION}

The existence of a minimum core breeding number of adults is required to start with and sustain even a small population, as was the case in the successively added and ameliorated area of Kanha in 1970s and 1980s (Panwar 2007). According to Kurup (1980), standing ungulate crop in a minimum area of $5.18 \mathrm{~km}^{2}$ is needed to sustain one tiger for one year in a sample habitat, and annual biomass increment of prey species per $2.59 \mathrm{~km}^{2}$ of habitat is about $336 \mathrm{~kg}$. Based on this, it is estimated that tiger population would require about $24 \mathrm{~km}^{2}$ of habitat per adult tiger to be stable and viable, using only the food increment and not the food capital stock. Such area is not available to the individual tigers in the small protected areas of northern Bengal. Only Buxa Tiger Reserve is the exception. Hence biological corridors may provide opportunities for linking protected areas lying adjacent to each other across international boundaries, and create habitat linkages for the tigers (Anon. 2006).

Chapramari and Gorumara have the potential for revival as tiger habitats. These two areas have a good population of herbivores like Gaur, Sambar, Chital, Barking Deer, Hog Deer, Wild Boar, etc. which form an excellent prey-base for prime carnivores like tiger. Such prey base is also available in Neora Valley and Mal Forest Block to the north and northwest of Chapramari, connecting corridors between these blocks, the relevant forests of Khumani Block of Kalimpong Forest Division and Panjhora, Selka, Sipchu and Hillajhora forest blocks of Jalpaiguri Forest Division. With increased measures of conservation, the entire area could help in protecting the rhinoceros and elephant populations in the context of their habitat and migration, and also open up the possibility of tiger descending down from Neora Valley National Park exploring its new territories amidst the rich potential preybase of Gorumara and Chapramari.

Again, an area of $30.82 \mathrm{~km}^{2}$ of the erstwhile 7 th Mile Range of Baikunthapur Forest Division has been included in Mahananda Wildlife Sanctuary since August 1996. This is also considered as a tiger habitat. Dispersal of individuals from this area to the east into the forest blocks of Baikunthapur is also not unlikely. This corridor may 
also be developed for the facility of conservation of the predator and prey species in this tract.

In addition to explorations for developing corridors and managing landscapes, it is also necessary to augment publicity programs in fringe areas to increase people's awareness on the tiger's ecological and cultural significance and the benefits of their conservation, notwithstanding their occasional depredation on the village cattle, for which compensation is being paid. The local Forest Protection Committees (FPCs) and Ecodevelopment Committees (EDCs) may also be involved in such programs as well as protection of the wildlife including the tiger and their habitat in northern West Bengal.

\section{REFERENCES}

Agrawal, V.C., P.K. Das, S. Chakraborty, R.K. Ghose, A.K Mandal, T.K. Chakraborty, A.K. Poddar, J.P. Lal, T.P. Bhattacharyya \& M.K. Ghosh (1992). Mammalia, pp. 112 In: State Fauna Series 4: Fauna of West Bengal, Part 1, Zoological Survey of India, Kolkata: 27-169.

Ahmad, Y.S. (1981). With the Wild Animals of Bengal. BRAC Printers. Dacca, 80pp.

Allen, B.C., E.A. Gait, C.G.H. Allen \& H.F. Howard (1993) (Reprint). Gazetteer of Bengal and North East India. New Delhi: Mittal Publications, 666pp.

Anon. (1930). How a Royal Bengal Tiger was Bagged. Journal of Darjeeling Natural History Society 4(4): 83-84.

Anon. (1969). Annual Report on Wildlife Preservation in West Bengal for the year 1967-68. Bulletin No.23, Planning and Statistical Cell, office of the Chief Conservator of Forests, West Bengal, Calcutta, 17pp.

Anon. (1971). Annual Report on Wildlife Preservation in West Bengal for the year 1968-69. Bulletin No.30, Planning and Statistical Cell, office of the Chief Conservator of Forests, West Bengal, Calcutta, 22pp.

Anon. (1976). Annual Report on Wildlife Preservation in West Bengal for the year 1973-74. Planning and Statistical Cell, office of the Chief Conservator of Forests, West Bengal, Calcutta, 33pp.

Anon. (1998) Tiger Conservation Initiatives in West Bengal. Wildlife Wing, Forest Department, Government of West Bengal, Kolkata, 16pp.

Anon. (2000). Biodiversity Conservation in West Bengal. Wildlife Wing, Directorate of Forests, Government of West Bengal, 100pp.

Anon. (2001). Annual Report of Wildlife Division-I 2000-2001, p.28. Darjeeling, 44pp.

Anon. (2004). Glimpse of Wildlife Statistics 2002-2003. Central Data Bank, Wildlife Wing, Headquarters, Forest Directorate, Government of West Bengal, Kolkata, 150pp.

Anon. (2006). Report of the Task Force on the Mountain Ecosystems [Environment and Forest Sector] for Eleventh Five Year Plan. Planning Commission, Government of India, New Delhi, 91pp.

Anon. (2008a). Annual Report 2007-08. Wildlife Wing, Directorate of Forests, Government of West Bengal, Kolkata, 90pp.

Anon. (2008b). Annual Report 2007-08. Directorate of Forests, Buxa Tiger Reserve (East) Division, Alipurduar, Jalpaiguri. 25pp+Annexures.

Anon. (undated). Tiger Action Plan for the Kingdom of Bhutan 2006-2015. Nature Conservation Division, Department of Forests, Ministry of Agriculture, Royal Government of Bhutan in collaboration with WWF Bhutan Program, Thimpu, Bhutan, $31 \mathrm{pp}$.
Bahuguna, N.C. \& J.K. Mallick (in press). Mammals of West Bengal and adjoining areas including Sikkim, Bhutan and Bangladesh. Natraj Press, Dehra Dun.

Baker, E.B. (1886). Sport in Bengal: How, When and Where to seek it. London: Ledger, Smith, \& Co., 368pp.

Baldry, T.A. (1926). The Tonglu Tiger. Journal of the Darjeeling Natural History Society 1(2): 80-82.

Barclay, E.N. (1931). Big Game Shooting Records, pp. 106-124. H.F. \& G. Witherby, London, 288pp.

Bhaduri, J.N. (1966). History of Cooch Behar District Forests, pp.103-106. West Bengal Forests, Centenary Commemoration Volume, Forest Directorate, Government of West Bengal, Calcutta.

Bhutia, P.T. (2005). Census Report $23^{\text {rd }}$ to $30^{\text {th }}$ November 2004 Wildlife Circle (North). Unpublished, Jalpaiguri, 39pp.

Bist, S.S. (1994). Population history of Great Indian Rhinoceros in North Bengal and major factors influencing the same. Zoos' Print 9(3\&4): 42-51.

Bist, S.S. (1997). 50-years of wildlife management in West Bengal. Banabithi Wildlife Special Issue: 31-37.

Biswas, G.G., D. Das \& A. Mukhopadhyay (1999). Richness of mammalian species in the higher elevations of Neora Valley National Park. Zoos' Print 14(4): 10-12.

Burton, R.G. (1989). The Book of the Tiger. Dehra Dun: Natraj Publishers.

Campbell, A.C. (1907). Glimpses of Bengal: A Comprehensive, Archaeological and Pictorial History of Bengal, Bihar and Orissa. Campbell \& Medland, 3 \& 4, Hare Street, Calcutta, 432pp.

Chaudhuri, A.B. \& D.D. Sarkar (2004). Project Tiger Reserves: Resources, Diversity, Sustainability, Ecodevelopment. Daya Publishing House, Delhi, 341pp.

Chaturvedi, M.D. (1970). The Felins, p.5. National Book Trust, New Delhi, India, 76pp.

Chaudhuri, A.B. \& K. Chakrabarti (1979). An ecological reconnaissance of 'Tiger' (Panthera tigris tigris Linnaeus) habitat and conservation of forest and wildlife, pp.193-207. Proceedings of the International Symposium on Tiger, India, February 22-24, 1979, pp.1-417+4.

Chaudhuri, H.N. (1903). The Cooch Behar State and its Land Revenue Settlements. Cooch Behar State Press, Cooch Behar, 705pp.+supplement.

Daniel, J.C. (2001). The Tiger in India: A Natural History. Natraj Publishers, Dehradun, 300pp.

Das, P.K. (1966). Jaldapara Wild Life Sanctuary, pp.251-258. West Bengal Forests, Centenary Commemoration Volume. Forest Directorate. Government of West Bengal, Calcutta.

Dinerstein, E., C. Loucks, E. Wikramanayake, J. Ginsberg, E. Sanderson, J. Seidensticker, J. Forrest, G. Bryja, A. Heydlauff, S. Klenzendorf, P. Leimgruber, J. Mills, T.G. O'Brien, M. Shrestha, R. Simons \& M. Songer (2007). The fate of wild tigers. BioScience 57(6): 508-514.

Dutt-Mazumdar, S. (1955). Wildlife of Darjeeling Hills. Journal of Bengal Natural History Society 27(4): 155-159..

Gayatri Devi \& S. Rama Rau (1982). A Princess Remembers - The Memoirs of the Maharani of Jaipur, pp. 62; 64-65; 66, 127. First Indian Edition, Sahibabad: Vikash Publishing House Pvt. Ltd, 335pp.

Ghosh, A. (1998). Tiger conservation - West Bengal chapter. Banabithi, Wildlife Issue, a periodical of the Government of West Bengal, Kolkata: 8-10.

Gruning, J.F. (1911). Eastern Bengal and Assam district Gazetteers. Jalpaiguri. Allahabad: Pioneer Press.

Guhathakurta, P. (1966). Mahanadi Wildlife Sanctuary, pp. 245-247. West Bengal Forests Centenary Commemoration Volume. Forest Directorate. Government of West Bengal, Calcutta.

Gupta, A.C. (1958). Gorumara Game Sanctuary. Journal of the Bengal Natural History Society 29(4): 132-139, 1 map, figs. 
1-4.

Harihar, A., B. Pandav \& S.P. Goyal (2009). Responses of tiger (Panthera tigris) and their prey to removal of anthropogenic influences in Rajaji National Park, India. European Journal of Wildlife Research 55(2): 97-105.

Hooker, J.D. (1854). Himalayan Journals or Notes of a Naturalist in Bengal, The Sikkim and Nepal Himalayas, the Khasia Mountains, etc. 631pp.

Inglis, C.M., W.L. Travers, H.V. O’Donel \& E.O. Shebbeare (1919). A tentative list of the vertebrates of the Jalpaiguri district, Bengal. Journal of Bombay Natural History Society 26(3): 819-825.

Jhala, Y.V., R. Gopal \& Q. Qureshi (eds.) (2008). Status of the Tigers, Co-predators and Prey in India. National Tiger Conservation Authority, Govt. of India, New Delhi, and Wildlife Institute of India, Dehradun, 164pp.

Kurup, G.U. (1980). Some parameters of tiger survival in India. Proc. Workshop "Wild Life Ecology" Dehra Dun, Jan. 1978, Ed. Director, Zoological Survey of India, Calcutta, pp. 87-98.

Kurup, G.U. (1989). The treasured tiger, pp. 412-431. In Majupuria, T.J. (ed.) Wildlife Wealth of India (Resources \& Management). Tecpress Service, L.P., Bangkok, Thairland, 667pp.

Lambourn, G.E. (1918). Bengal District Gazetteers. Malda. Calcutta: Bengal Secretariate Book Depo.

Mallick, J. \& I. Mitra (2002). Biodiversity Resource Assessment and Management of Buxa Tiger Reserve through GIS. Wildlife Wing, Directorate of Forest. Govt. of West Bengal. Kolkata. Unpublished, 60pp+maps.

Maraj, R. \& J. Seidensticker (2006). Assessment of a Framework for Monitoring Tiger Population Trends in India. A Report to the IUCN: World Conservation Union and India's Project Tiger, 33pp.

Martin, E.B. (1996). The importance of park budgets, intelligence networks and competent management for succesfu conservation of the Greater One-horned Rhinoceros. Pachyderm 22: 10-17.

Mishra, A.K. (1998). Potential Threats from Proposed Developmental and Mining Projects on Wildlife Values of Buxa Tiger Reserve. Management Term Paper (unpublished). Wildlife Institute of India.

MoEF (2000). Report of the Committee on identifying parameters for designating ecologically sensitive areas in India. Ministry of Environment \& Forests, Government of India, New Delhi.

Nandy, S. (2006). Wild Cats of West Bengal. West Bengal October, 11-16pp.

Narain, V. (1927). Encounter between wild buffalo and a pair of tigers. Journal of Bombay Natural History Society 31: 1025.

Nripendra Nārāyana Bhūpa (Mahārājah of Cooch Behār) (1908). Thirty-Seven Years of Big Game Shooting in Cooch Behar, the duars and Assam: A rough Diary, pp. 411-414. The Times Press, Bombay, 461pp.

O'Malley, L.S.S. (1907). Bengal District Gazeteers. Darjeeling Logos Press, New Delhi, 12-13pp.

Panwar, H.S. (2007). Why tigers are not reoccupying Kuno despite excellent ameliorated and productive habitat? Zoos' Print 22(7): 18-19.

Peissel, M. (1966). Tiger for Breakfast: The Story of Boris of Kathmandu. New York: E.P. Dutton \& Co., Inc. 282pp.

Pocock, R.I. (1941). The fauna of British India, including Ceylon and Burma. Mammalia. Vol.II. Carnivora. Taylor \& Francis, London.

Prasad, U.V.S. (2002). Draft Final Report Study on Documentation of the Ecological History of Duars with special reference to Buxa Tiger Reserve under the Eco Development Project for the Directorate of Forest and Wild Life, West Bengal, 92pp.

Pratihar, S. \& S. Chakraborty (1996). An account of the mammalian fauna of Gorumara National Park, Jalpaiguri, West Bengal. Records of Zoological Survey of India 95(3):
3-4.

Raha, A.K. (ed.) (1996) Wildlife Conservation in West Bengal: A Decade at a Glance. Wildlife Wing, Forest Department, Government of West Bengal, Kolkata, 58pp.

Rajvanshi, A., V.B. Mathur, G.C. Teleki \& S.K. Mukherjee (2001). Roads, Sensitive Habitats and Wildlife: Environmenta Guideline for India and South Asia. Wildlife Institute of India, Dehradun and Canadian Environmental Collaborative Ltd., Toronto, 215pp.

Reddy, G.V. (2008). Lessons from two local extinctions: Sariska and Kailadevi (Ranthambhore) in Rajasthan, India. Conservation and Society 6(3): 256-262.

Rodgers, W.A. \& H.S. Panwar (1988). Planninga Wildlife Protected Area Network in India: The Report. Vol. 1-2. Wildlife Institute of India, Dehradun, 267pp.

Russell, C.E.M. (1900). Bullet and Shot in Indian Forest, Plain and Hill with hints to beginners in Indian shooting. W. Thacker and Co., London, 542pp.

Sanyal, P. (1992). Tiger reserve - pride of North Bengal. West Bengal 34(19): 397-398.

Sanyal, P. (2006). Tiger crisis: Anthropogenic or natural. Annual Report 2006, Retired IFS Officers Association, West Bengal, Kolkata, 38-39pp.

Sengupta, J.C. (1965). West Bengal District Gazetteers. West Dinajpur. Government of West Bengal, Calcutta.

Sengupta, J.C. (1969). West Bengal District Gazetteers. Malda. Government of West Bengal, Calcutta.

Sterndale, R.A. (1982). Natural History of the Mammalia of India and Ceylon (A New Unbridged Edition). First Indian Reprint, Himalayan Books, New Delhi, 540pp.

Sunder, D.H.E. (1889-95). Final Report on the Land Revenue Settlement of the Western Dooars in the Jalpaiguri District, Section VI, Wild Animals (Large), Game Birds and Snakes. Calcutta, 15-27pp.

Thapliyal, G.B. (2001). Biodiversity conservation in West Bengal. West Bengal 43(20): 5-17.

Ward, R. (1903). Records of Big Game with the Distribution, Characteristics, Dimensions, Weights, and Horn \& Tusk Measurements of the Different Species. R. Ward Limited (London), xiii, 495pp.

WLW, WBFDCL \& NEWS (1996). Survey of Flora and Fauna of Mahananda Wildlife Sanctuary. A Collaorative Research Project of Wildlife Wing, Forest Department, West Bengal, West Bengal Forest Development Corporation Ltd. and Nature Environment \& Wildlife Society, Kolkata, 34pp+photographs

Wood, H.S. (1937). Observations on the Tiger and its Shikar. Journal of Bengal Natural History Society 12(2): 66-68.

Working Plans (North) Division (2001). Area Distribution and Notification of Divisions of North Bengal. Government of West Bengal, Directorate of Forests, Darjeeling, 78pp.

Wroughton, R.C. (1916a). Bombay Natural History Society's Mammal Survey of India, Burma and Ceylon. Report No. 23. Sikkim and Bengal terai. Journal of Bombay Natural History Society 24(3): 468-493.

Wroughton, R.C. (1916b). Bombay Natural History Society's Mammal Survey of India, Burma and Ceylon. Report No. 26. Darjiling District. Journal of Bombay Natural History Society 24: 773-782

Wroughton, R.C. (1917a). Bombay Natural History Society's Mammal Survey of India, Burma and Ceylon. Report No. 27. Bhutan Duars. Journal of Bombay Natural History Society 25: 63-71.

Wroughton, R.C. (1917b). Bombay Natural History Society's Mammal Survey of India, Burma and Ceylon. Report No. 28. Kalimpong (Darjiling). Journal of Bombay Natural History Society 25: 274-278.

Yadav, V.K. (1998). Dwindling Elephant Corridor. Environ 6(2): 26-45. 
Yadav, V.K. (2001). Wildlife conservation in West Bengal. Banabithi, Wildlife Issue, Kolkata, 25-29pp.

Yadav, V.K. (2004a). The denizens of Darjeeling hills. Banabithi, Wildlife Issue, Kolkata, 34-36pp.

Yadav, V.K. (2004b). Wildlife conservation in West Bengal. West Bengal 46(10): 8-13.

\section{Editor's Note:}

\section{Corridors and landscapes for tiger and sympatric species}

"The concept of forest corridors, specially conceived for elephant management, could additionally ensure the exchange of genes from adjacent areas so that ......the majestic tiger in tawny and black continues to reign in the forest habitat." Although written about ten years back in the context of elephant and tiger (Singh 1999: pp. 56), the concept applies for conservation of tiger and its other sympatric species. The present account on tigers of northern West Bengal highlights potentialities for landscape-level management of tiger by encompassing the entire area of NeoraChapmari-Mahananda-Gorumara, and also through Jaldapara-Buxa. This is expected to benefit elephant and rhinoceros, as well. Landscapes listed in the work edited by Jhala et al. (2008) across 'North East Hills and Bramhaputra Flood Plains', particularly the Manas - Ripu Chirang - Buxa/ Jaldapara - Gorumara - Singhalila landscape, offer a base for further evaluation and development of management prescriptions for tiger across national and international borders. Trans-boundary prescriptions are assuming increased significance in the light of improving vegetation in and around habitats of isolated tiger populations and increasing information about tigers moving out to newer areas.

Young tigers, after passing through their cub-hood in the company and guidance of mothe tigress, may move away a lot from the natal area while exploring to reach and establish a 'territory' of their own. In the state of Orissa, after gap of 'several decades', tigers have been tracked and seen outside Similipal Tiger Reserve in Satkosia RF of Karanjia Forest Division in January 2004 and in Kuldiha Sanctuary in March 2009. These are viewed as consequences of southward shifting of tigers and confirm to the observed behaviour of the tiger population in Similipal (Singh 1995; Prusty \& Singh 1996; Srivastava \& Singh 1997). Efforts are on for consolidating a corridor through Similipal-Hadgarh-Kuldiha in this landscape. The present study on northern West Bengal chronicles a few instances within the study area and elsewhere in India which may appear as stray movements. There may be more records elsewhere in the tiger range, which have skipped serious attention and analysis from managerial view point. Possibly, too much of 'anthropocentric management activities', in whatsoever form, have already reached within most of the "tiger-rich" areas, as a result of which tiger, as an evolutionary survival strategy, is on a spree of exploration and evaluation of new homes. The qualified corridors through which straying tigers move and the habitats still supporting reminiscent isolated populations of tiger constitute the nuclei for directing and developing strategies for management of tiger landscapes in future.

\section{References}

Jhala, Y.V., R. Gopal \& Q. Qureshi (eds.) (2008). Status of the Tigers, Co-predators and Prey in India, pp.130 and 163. National Tiger Conservation Authority, Govt. of India, New Delhi, and Wildlife Institute of India, Dehradun. TR 08/001, 164pp.

Prusty, B.C. \& L.A.K. Singh (1996). Trend of population of tiger and leopard in Similipal Tiger Reserve: a conservation concern. Indian Forester 122(10): 865-868.

Singh, L.A.K. (1995). Sex-identification technique and sex-ratio in tiger: doubts and clarifications. Indian Forester 122(10): 885-894.

Singh, L.A.K. (1999): Born Black: The Melanistic Tiger in India. WWF-India, New Delhi 1999, viii+66pages.

Srivastava, S.S. \& L.A.K. Singh (1997). Future trend of tiger population in Similipal Tiger Reserve. Indian Forester 123(10): 902-909. 